\title{
Spatio-temporal Analysis of Urban Growth and Its Effects on Wetlands in Rwanda: The Case of Rwampara Wetland in the City of Kigali
}

\section{*1,3 RWANYIZIRI, G; ${ }^{2}$ KAYITESI, C; ${ }^{3}$ MUGABOWINDEKWE, M; ${ }^{4}$ BYIZIGIRO, RV; ${ }^{3}$ MUYOMBANO, E; ${ }^{5}$ KAGABIKA, MB; ${ }^{6}$ BIMENYIMANA, T}

\author{
${ }^{*}$ Department of Geography and Urban Planning, College of Science and Technology, University of Rwanda, P.O. Box 3900, Kigali, \\ Rwanda \\ ${ }^{2}$ Clinton Health Access Initiative, Kigali, Rwanda \\ ${ }^{3}$ Centre for Geographic Information Systems and Remote Sensing, College of Science and Technology, University of Rwanda, P.O. Box \\ 3900, Kigali, Rwanda; \\ ${ }^{4}$ Division of Geography, College of Education, University of Rwanda, Rukara Campus, P.O. 55 Kayonza, Rwanda \\ ${ }^{5}$ Department of Development Studies, Kigali Independent University, P.O. Box 2280 Kigali, Rwanda; \\ ${ }^{6}$ Department of Environmental Studies, The Open University of Tanzania, P.O. Box 23409 Dar es Salaam, Tanzania.
}

*Corresponding Author Email: grwanyiziri@gmail.com; Tel.: +250788681438

\begin{abstract}
This study aimed at analyzing the spatio-temporal patterns of urban growth and its effects on Rwampara wetland, located in the City of Kigali, Rwanda. First, the study was based on the application of remote sensing technology, where 4 Landsat images (1987, 1999, 2009 \& 2018) were classified using maximum likelihood classification algorithm. This helped in analyzing the Land Use and Land Cover (LULC) trends in the study area. Secondly, it used the existing LULC data for the years 1990, 2000, 2010 and 2018 in order to investigate the overall changes in LULC in Kigali City. Finally, semi-structured interviews were used to collect data from local people and decision-makers about their past and future management strategies of Rwampara wetland. In this regard, 30 local communities (mainly natives from the study area), 15 local government authorities at sector and district levels as well as 4 senior government authorities in the central administration were interviewed. The findings revealed that over the past 4 decades, urban growth in Kigali City has rapidly increased at the expense of resource degradation in Rwampara wetland. Specifically, there has been an increase of about $77 \%$ of the built-up area over the last 31 years (1987-2018) which has led to the decrease of the wetland surface area from 24 ha in 1987 to only 7.7 ha in 2018. The results also revealed that demographic factors (i.e. a high population growth rate and high population densities) were mainly responsible for urban growth and degradation of wetland resources in the area under investigation.
\end{abstract}

DOI: https://dx.doi.org/10.4314/jasem.v24i9.2

Copyright: Copyright (C) 2020 Rwanyiziri et al. This is an open access article distributed under the Creative Commons Attribution License (CCL), which permits unrestricted use, distribution, and reproduction in any medium, provided the original work is properly cited.

Dates: Received: 02 August 2020; Revised: 26 August 2020; Accepted: 20 September 2020

Keywords: urban growth, wetland, wetland resources, wetland degradation, wetland management

Located in the eastern part of the African continent, Rwanda has been experiencing an urban revolution that poses a major environmental challenge across the globe (Dixon and Wood, 2003). Currently, the country's annual urban growth $(4.5 \%)$ largely exceeds the global average (1.8\%) (REMA, 2015). In addition, its population density (495 inhabitants $/ \mathrm{km}^{2}$ in 2018) ranks among the top 5 highest population densities in Africa (Imasiku and Ntagwirumugara, 2019). Consequently, both rapid urbanization and population growth are posing serious threats on wetland resources in both rural and urban areas (Rwanyiziri et al., 2019; Nabahungu and Visser, 2011; Rwanyiziri and Rugema, 2013). Most importantly, these effects have had a more predominant effect in urban areas, especially in the City of Kigali compared to elsewhere. Apart from high population densities, other major causes of these negative impacts on wetland resources are linked to development activities done in Kigali City such as industries, human settlements, trade and transport facilities, urban agriculture, among others (UNEP, 2011). Currently, only 24\% of Kigali City's original wetlands have survived (REMA, 2015). Like other wetlands in Kigali City, Rwampara wetland is facing the above-mentioned threats in addition to having its water drained to River Nyabugogo, one of the main water sources in the city (Sano, 2007). Therefore, the degradation of Rwampara wetland constitutes an alarming environmental problem that has not been given due attention when it comes to addressing issues related to water and wetlands management in Kigali City. According to various studies, the degradation of Rwampara wetland resources started in the 1980 s when local communities 
used many wetlands in City of Kigali for agriculturerelated purposes. Prior to that period, these wetlands were, in fact, considered as marginal lands or just mere dumpsites (UNEP, 2011). The aim of this study was to analyze the spatio-temporal patterns of urban growth in the City of Kigali and their effects on Rwampara wetland resources. Specifically, the study sought to investigate major drivers of urban growth in Kigali City and the extent to which these have contributed to the degradation of Rwampara wetland resources. Finally, the study proposes some effective strategies towards better management of the wetland under investigation.

\section{MATERIALS AND METHODS}

Study Area: This study was conducted in Kigali, the capital city of Rwanda, the largest and rapidly growing city in the country. The city covers a surface area of $730 \mathrm{~km}^{2}$ and is subdivided into three administrative districts of Gasabo $\left(429.3 \mathrm{~km}^{2}\right)$ in the North and North East, Kicukiro $\left(166.7 \mathrm{~km}^{2}\right)$ in the South and South East and Nyarugenge $\left(134 \mathrm{~km}^{2}\right)$ in the West. The study focused on Rwampara wetland that crosses two districts of Nyarugenge and Kicukiro (Fig. 1). This wetland is an important source of water that has direct positive impacts on different activities in the city such as urban agriculture, construction, etc. (UNEP, 2011).

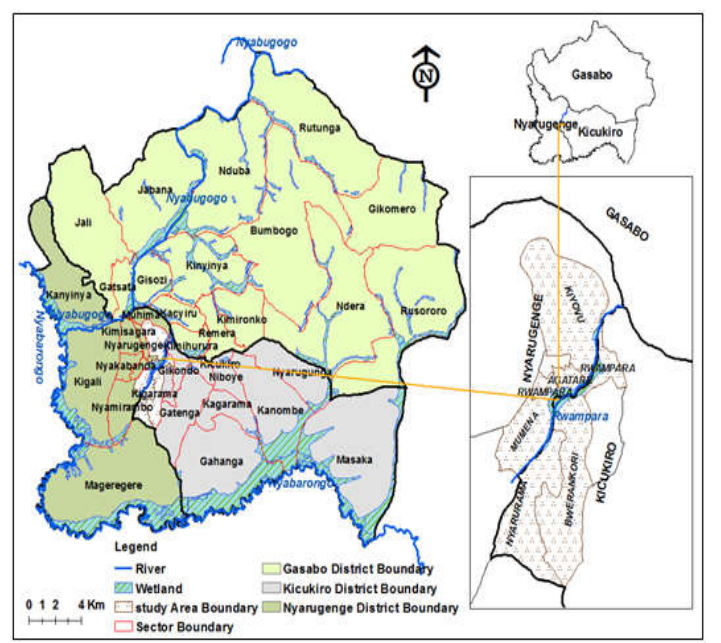

Data Collection Methods: Both secondary and primary data were collected and analyzed in this study. For secondary data, a well-consolidated literature on wetland management in Rwanda and around the world was reviewed. In addition, the study relied on existing spatial data-sets from different sources. Finally, the study used available Landsat images from the United States Geological Survey (USGS) repository for fourtime periods (1987, 1999, 2009 and 2018). Regarding the primary data, field observation and face-to-face semi-structured interviews were conducted to ensure that the analysis reflected various converging evidences. In total, 30 local people (mostly composed of natives from the study area) with a good historical background of the wetland under investigation and its management were purposefully selected and interviewed. In addition, semi-structured interviews targeted 15 local decision makers at sector and district levels as well as 4 senior government authorities from the City of Kigali and the Ministry of Infrastructure. The questions mainly focused on the challenges encountered by the respondents as well as their future plans.

Data Processing and Analysis: Remote sensing analysis with Landsat image classification was the main research method used for this study. This classification was made on the basis of a supervised classification approach, which is an essential tool for extracting quantitative information from remotely sensed data (Mugabowindekwe and Rwanyiziri, 2020). Maximum Likelihood Classifier algorithm (MLC) was also used basing on the assumption that each spectral class can be described by a multivariate normal distribution. The image classification exercise led to the identification of both spatial and temporal changes which, over the time, have been taking place in Kigali City, especially in Rwampara wetland. The following table presents the accuracy assessment of the classified images where both the Producers and Users' Accuracy were calculated. Apart from the above calculation, another calculation of Kappa coefficient and an overall accuracy of classified images were also done and established, respectively.

Fig. 1. Map of the Study Area (CGIS, 2019)

\begin{tabular}{|c|c|c|c|c|c|c|c|c|}
\hline \multirow[t]{2}{*}{ Year } & \multicolumn{3}{|c|}{ Producer's Accuracy (\%) } & \multicolumn{3}{|c|}{ User's Accuracy (\%) } & \multirow{2}{*}{$\begin{array}{l}\text { Kappa } \\
\text { Coefficient }\end{array}$} & \multirow{2}{*}{$\begin{array}{l}\text { Overall } \\
\text { Accuracy }\end{array}$} \\
\hline & Built-up & Non Built-up & Wetlands & Built-up & Non Built-up & Wetlands & & \\
\hline 1987 & 93.6 & 99.1 & 90.7 & 90.5 & 97.6 & 92.3 & 0.9 & 94.3 \\
\hline 1999 & 98.7 & 95.5 & 92.7 & 93.9 & 98.8 & 91.1 & 0.9 & 95.3 \\
\hline 2009 & 96.2 & 97.1 & 898 & 94.4 & 95.1 & 83.1 & 0.9 & 91.7 \\
\hline 2018 & 99.7 & 88.9 & 91.3 & 90.7 & 98.9 & 88.4 & 0.9 & 96.1 \\
\hline Average & 97.1 & 95.1 & 91.1 & 92.4 & 97.6 & 88.7 & & \\
\hline
\end{tabular}

As presented in table 1, the overall accuracy of the four classified images (1987, 1999, 2009 \& 2018) was about $94.3 \%$, while the Kappa coefficient was about 0.9. After these calculations, the GIS tool was used to

RWANYIZIRI, G; KAYITESI, C; MUGABOWINDEKWE, M; BYIZIGIRO, RV; MUYOMBANO, E; KAGABIKA, $M B ; B I M E N Y I M A N A, T$ 
improve the remote sensing image classification by producing maps for better visualization of results. Thereafter, the Fragstat tool was used to compute the statistics involved in each land cover class, and this assisted in quantifying the landscape composition. Finally, all these tools and techniques were used to get a better understanding and representation of Kigali City urban growth and its impact on Rwampara wetland in terms of statistical metrics.

\section{RESULTS AND DISCUSSION}

Major Drivers behind the Dynamics of Urban Growth in the City of Kigali: In space and time, some major factors have been identified as the main drivers of urban growth in Rwanda, especially in Kigali City. These mainly include demographic, economic and biophysical factors as well as factors related to neighborhood and proximity characteristics. As far as demographic factors are concerned, the country's population has critically increased from 4.8 million in 1978 to 10.5 million in 2012 and the percentage of the people living in urban areas has also followed a similar trend (from $4 \%$ of the total population in 1978 to 16.5 $\%$ in 2012) (Imasiku and Ntagwirumugara, 2019; UNEP, 2011). On this point, the findings of this study are corroborated by other studies by Khan et al., (2014) and Ma et al., (2012) who argued that the ultimate effect of rapid population growth in a given country is associated with rapid urban growth its cities and towns. According to the above authors, rapid population growth is also linked to the changes in land cover and land use patterns, including the degradation of wetlands. Regarding the economic factors, they are known to be one of the major drivers behind rapid urban growth due to their economic-pulling dynamics. In the City of Kigali, these dynamics include the availability of affordable residential and business houses as well as the availability of clients to occupy the proposed business, among others. This study also found that the availability of affordable business houses was the highest influencing factor that contributed to urban growth in Kigali. The above factor is followed by the availability of affordable residential houses and the availability of clients within the neighborhood. Concerning the role of biophysical factors such as slopes and soil types, it was found that the former have had a high influence on urban growth in Kigali City due to their sharp steepness that makes some areas inappropriate for the development of the building and construction industry, especially for residential purposes. As confirmed by other studies, soil types also have a moderate influence on urban growth due to their poor fertility in wetlands and lowlands (REMA, 2015; UNEP, 2011). Finally, the neighborhood and proximity amenities such as electricity and water provision, the proportion of the built-up area, accessibility to paved roads, distance from and to schools and health facilities, distance to centers and sub-centers (Kigali City is a central business district) have been found to have a great influence on urban growth. This is also linked to the migration and settlement patterns of many young people who prefer to be closer to urbanized neighborhoods for employment opportunities. Consequently, most of the socio-economic development activities have tended to be concentrated around major roads and areas with regular availability of electricity and water. Therefore, these patterns have had a high incidence on urban development in the area under study as well as in other parts of the city.

Observed Spatio-Temporal Dynamics of Urban Growth in the City of Kigali: An analysis of the existing data indicated that there has been a considerable number of changes in terms of land use trends and land cover types in Kigali city in the last 28 years, resulting into a high rate of expansion of the city's urban built-up area compared to other LULCs (Fig. 2).

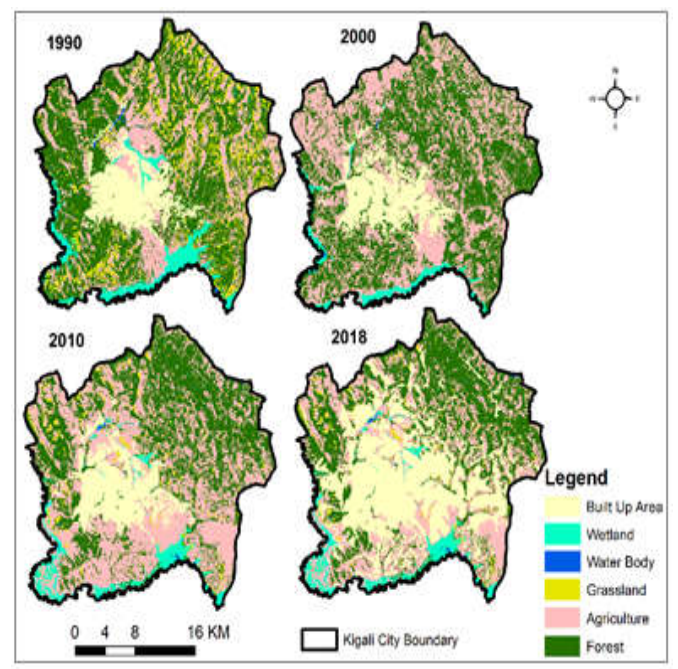

Fig. 2. Dynamics of Land Use and Land Cover (LULC) in Kigali City (1990-2018); (RCMRD, 2015 \& RWFA, 2018)

As indicated in the previous paragraphs, urban growth in Rwanda has gradually had serious effects not only on wetland resources, but also on other land use trends and land cover types. These effects are both positive (i.e. economic growth from the exploitation of natural resources) and negative (i.e. biodiversity loss, shrinkage of agricultural and forest lands, etc.). By specifically looking at the area under investigation and, using the image classification analysis of the available Landsat images for 4 different decades (1987, 1999, 2009, and 2018), it can be argued that urban growth has rapidly increased, leading to a

RWANYIZIRI, G; KAYITESI, C; MUGABOWINDEKWE, M; BYIZIGIRO, RV; MUYOMBANO, E; KAGABIKA, $M B ; B I M E N Y I M A N A, T$ 
gradual depletion of resources in Rwampara wetland (Fig. 3). For purposes of this analysis, the LULC includes water bodies, grassland, agriculture (cropland) and forest zone that has been merged into one category labeled as "non-built up" zone.

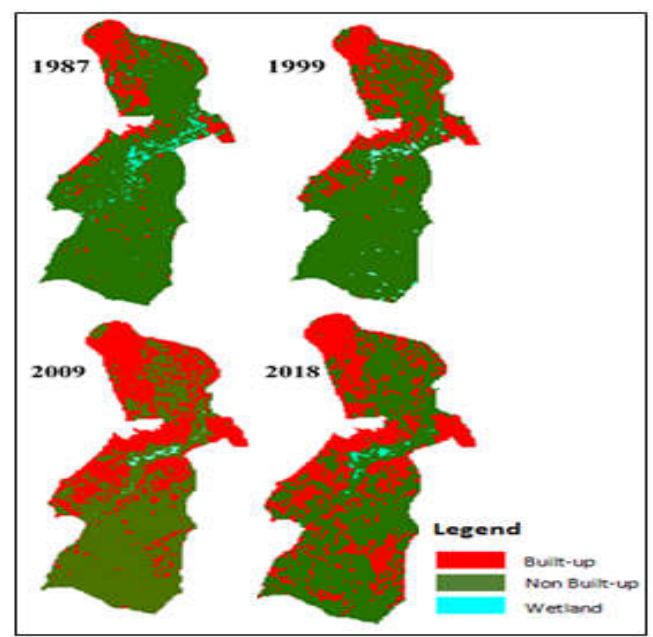

Fig. 3. Land Use Dynamics around in and around Rwampara Wetland (1987-2018) (RCMRD, 2015 \& RWFA, 2018)

As presented in figure Fig. 2, the built-up area has been increasing, hence threatening other land use and/cover types in and around Rwampara wetland (see Fig. 3). The image classification results demonstrated that the built-up area has experienced an increase of about $77 \%$ over a period of 31 years, while the wetland has been either lost or degraded, resulting into a decrease of the wetland area from 24 ha (in 1987) to only 7.7 ha (in 2018), implying a total area loss of about 16.3 ha $(68 \%)$. The degradation and fragmentation of Rwampara wetland was analysed using landscape metrics as well as the fragstats tool to cover all fragmented patches. Accordingly, it was found that the number of patches (fragmentation) in the wetland land cover classification had also progressively increased. For instance, in 1987, Rwampara wetland accounted only for 19 patches, and later 26 patches in 1999 , then 64 patches in 2009, and ultimately 100 patches in 2018. This fragmentation and degradation of the wetland mainly resulted from the dynamics of rapid urban growth.

Effects of Urban Growth dynamics on Rwampara Wetland Resources: As per the interviewed elders (natives) in the study area, local leaders, and decision makers responsible for urban planning and environmental management, this study revealed that rapid urban growth has caused critical impacts on Rwampara wetland resources, especially on water and land resources. The mentioned impacts are associated with soil loss, land degradation, land fragmentation, decrease in water quantity and availability, decrease of agricultural productivity, and a critical shortage of water within the city. In addition, Rwampara wetland has become one of the areas in Kigali city that are facing frequent and destructive urban flash floods (Perez-Molina et al., 2016). On this point, Death et al., (2015) have argued that urban extreme floods have remarkably increased in urban areas around the world and this has caused serious threats, especially on river hydrology systems. The main impacts associated with urban growth dynamics on Rwampara wetland resources as identified in this study are, first and foremost, the change of land use from the wetland to other development activities, especially the construction of residential and commercial buildings as well as road infrastructure., In addition, other impacts include increased flash floods risks as well as decreased water supply in the city.

Land Use Change from Wetland to other Developmental Activities: Despite the important role played by urban wetlands, they are nonetheless subjected to countless pressures that result into their loss and/or degradation Murungweni (2013). The threats to urban wetlands range from urban sprawl, new infrastructure development (construction of new roads, buildings, recreation facilities, etc.), and pollution from human waste which has been caused by domestic and/or industrial use. Nowadays, wetland resources are threatened by being drained and fragmented with consequences of diversions of water supplies, and construction of infrastructures such as residential houses in the wetlands. This study found that the most observed changes which have had frequent impacts on Rwampara wetland include: new infrastructure development such as roads, residential and commercial buildings. Consequently, the wetland under investigation has been experiencing fragmentation, decrease of wetland surfaces (Fig. 8), wetland fragmentation, and consequently, a decline of wetland productivity, particularly in terms of agricultural production.

Increased Risks of Flash Floods: As noted by Arrighi et al., (2017) and Hickey and Salas (1995), flash flood events in urban areas are likely to increase over time and the dynamics of urban population growth are responsible for increasing extreme floods. In Kigali city, Rwampara is one of the areas (apart from Nyabugogo, Kinamba, Kanogo, Rugunga, Mulindi, and Gikondo-MAGERWA) that have been experiencing extreme flash flood events during the rainy season in the city (Perez-Molina et al., 2016). It has been noted that this is mainly due to lack of storm water management strategies and lack of 
infrastructures to accommodate peak runoff accumulation from upstream areas such as Gikondo, Nyamirambo and Kiyovu. Furthermore, this study found that flood risks are on an increasing trend due to the development of new infrastructures and buildings (especially informal settlements/slums) where domestic water is not controlled owing to limited water harvesting systems and lack of adequate water channels.

Decreased Water Supply to the City: Previous studies have shown that wetlands are a key ecosystem that provides vital water resources and other key services in urban areas (Mcinnes, 2010). Similarly, Rwampara wetland has previously been recognized as one of the key sources of water to the City of Kigali. However, this wetland has suffered from serious degradation coupled with the depletion of its water resources. In many places water taps installed within the wetland show limited water supply in terms of quantity. It can therefore be argued that unless adequate interventions are made, there is a likelihood of experiencing decreased water channels to the wetland with possible water loss in the near future. Nonetheless, the wetland continues to be a source of water for daily use within the households in the wetland's neighborhoods. Unfortunately, continuous urban growth and a high population density in Kigali City have resulted into over-exploitation of Rwampara wetland and its water resources (mainly for construction and agricultural activities) which has led to a significant decrease of its water supply to the city.

Proposed Effective Strategies towards Sustainable Management and Use of Rwampara Wetland Resources: Strict Implementation of Existing Policies and Regulations: In Rwanda, many laws, policies and regulations have been established with regard to wetland protection and natural resources management. These include the law governing biodiversity in Rwanda, the organic law determining the modalities of protection, conservation and promotion of environment policies in Rwanda, Rwanda Biodiversity Policy, and many others. This is in addition to a number of research outputs and related recommendations. However, the present study has revealed that most of these policy frameworks are not strictly implemented, resulting into many negative effects on wetland resources as mentioned in the foregoing statements. Therefore, it is suggested that existing policies should be strictly implemented before looking for alternative solutions for sustainable urban management.

Raising Awareness of the Population about Sustainable Use of Wetland Resources: This study has established that wetlands provide vital ecosystem services. However, it has been found that their socioeconomic and environmental values are not well recognized by local communities. Urban growth is gradually rapidly increasing while wetlands continue to face degradation and loss over time. The findings of the present study have also revealed that the main factor responsible for this is the over-exploitation of the wetland ecosystem. Therefore, strong awareness programs and related projects are highly recommended for the local people to understand and own the values and functions of wetlands. In addition, there should also be a wise use of wetlands that keeps a balance between urban growth and wetland management. In fact, the promotion of resource ownership is a critical factor in achieving sustainable urban growth and development.

Involving the Local Population in the Establishment and Implementation of Measures and Strategies towards a Wise use of Wetland Resources: Apart from sensitizing the population on the wise use of wetlands, local communities should be fully involved in planning and implementing all measures and strategies for wetland management. This is based on the fact that they are the key stakeholders in managing these fragile ecosystems, and are therefore the direct beneficiaries of all offered services, and in case of inability to provide these services; the local communities are the first to experience any accruing hardship. Therefore, this study suggests that local communities should be involved at every phase of planning and implementing programmes related to wetland management. The interviewed natives in Rwampara wetland and its neighborhoods revealed that if fully involved, they would participate in activities related to the sustainable management of the wetland and would become stewards of the wetland ecosystem. Lastly, they also said that if they are fully involved, they would strive to maintain the ecological balance of the wetland ecosystem by managing its resources wisely.

Putting in Place Water Harvesting Systems in Rwampara Catchment Area and Upgrading of Informal Settlements: As confirmed by the primary and secondary data sources, it can be deduced that Rwampara wetland has been facing major flood risks. This has resulted into soil loss for agriculture, especially during the rainy seasons. This is due to the fact that most of the households in the wetland catchment area do not have water-harvesting mechanisms. Consequently, all domestic waters end up being drained into Rwampara wetland. Therefore, the present study suggests that water-harvesting mechanisms should be put in place to help the mitigation of flood risks. This would also contribute to 
the prudent use of the wetland's water resources. In addition, this study recommends that the informal settlements should be upgraded. This is based on the findings that Rwampara, and other urban wetlands, are being threatened by uncontrolled domestic waters resulting from unplanned settlements in the city.

Establishing Strategies for Systematic and Regular Monitoring of Wetland Use and Management: To achieve the goals and targets set for wetlands sustainability, a mandatory systematic approach should be put in place to conduct regular monitoring on the use and management of the wetlands in the country, including urban wetlands. It is one thing to put in place strategies for certain purposes, but it is also another to establish regular monitoring and evaluation mechanisms for their implementation. The present study has found that consistent, thorough and timely wetland monitoring systems and assessment programs are very critical in improving the management and protection of wetland resources. In fact, this would contribute to establishing a wetlands' inventory that includes their conditions and functions. It would also assist in detecting changes and documenting trends over time. Most importantly this inventory would help decision makers to restore and rehabilitate wetlands whenever deemed necessary.

Conclusion: Over the past 28 years, many changes have happened in Kigali City. These changes have caused serious negative impacts on wetland resources. For the case of Rwampara wetland, the present study has identified these negative effects to include but not limited to risks of urban flash floods, decrease of water supply from wetland to the city, and land use changes from wetland nature to other development activities such as roads, residential and commercial buildings. In solving this problem, there is a need to establish effective strategies towards better sustainable management of Rwampara wetland.

\section{REFERENCES}

Arrighi, C; Tarini, F; Vicario, E; Castelli, F (2017). Flood impacts on a water distribution network. Nat. Hazards Earth Syst. Sci. 17: 2109 - 2123.

Death, RG; Fuller, IC; Macklin, MG (2015). Resetting the river template: The potential for climaterelated extreme floods to transform river geomorphology and ecology. Freshw. Biol. 60(12): $2477-2496$.

Dixon, AB; and Wood, AP (2003). Wetland cultivation and hydrological management in eastern Africa: Matching community and hydrological needs through sustainable wetland use. Nat. Resour Forum 27(2): 117 - 129.

Hickey, JT; Salas, JD (1995). Environmental Effects of Extreme Floods. Hydrometerology, impacts and management of extreme floods. Research Workshop on the Hydrometeorology, Impacts, and Management of Extreme Floods. Perugia, Italy

Imasiku, K; Ntagwirumugara, E (2019). An Impact Analysis of Population Growth on Energy-WaterFood-Land Nexus for Ecological Sustainable Development in Rwanda. Food and Energy Secur 00:e185: 1- 17

Khan, AA; Arshad, S; Mohsin, M (2014). Population Growth and its Impact on Urban Expansion: A Case Study of Bahawalpur, Pakistan. Universal Journal of Geoscience 2(8): $229-241$

Ma, Y; Shen, Z; Zhou, D; Wang, K (2012). A Planning Tool for Simulating Urban Growth Process and Spatial Strategy of Urban Development in Chuandong, China. In: Shen Z. (Eds). Geospatial Techniques in Urban Planning. Advances in Geographic Information Science. Springer: Berlin/Heidelberg, pp. $27-48$

Mcinnes, R (2010). Urban and peri-urban wetlands : Background and update on progress, (December). Ramsar Workshop of the STRP NFPs in Africa, Johannesburg, $30^{\text {th }}$ November $-2^{\text {nd }}$ December 2010

Mugabowindekwe, M; Rwanyiziri, G (2020). Comparative Assessment of Homogeneity Differences in Multi-Temporal NDVI Strata and the Currently Used Agricultural Area Frames in Rwanda. S. Afr. J. Geomat. 9(1): $89-107$

Murungweni, FM (2013). Effect of Land Use Change on Quality of Urban Wetlands: A Case of Monavale Wetland in Harare. Geoinformatics \& Geostatistics: An Overview S1: $1-5$

Nabahungu, NL; Visser, SM (2011). Contribution of Wetland Agriculture to Farmers' Livelihood in Rwanda. Ecol. Econ. 71: 4 - 12

Perez-Molina, E.; Sliuzas, RV; Van Maarseveen, MFAM; Jetten, VG (2016). Urban Flood Management under Rapid Growth in Kigali, Rwanda: Developing Perspectives on Land Use Planning and the Future by Exploring the Case of the Rwampara Wetland. In: H. D. Schmitt H. D. 
(Ed.). Proceedings of Dortmund conference 2016: Spatial Patterns - Structure, Dynamic, Planning, 22-23 February 2016, Dortmund: Germany (pp. 351-365). Essen: Klartext Verlag

RCMRD (2015). Rwanda Land Cover 2015 Scheme I. Nairobi: Regional Centre for Mapping of Resources for Development. Available at http://opendata.rcmrd.org/datasets?q=Rwanda [Accessed 14 Dec. 2018]

REMA (2015). Rwanda State of Environment and Outlook Report 2015. Kigali: Rwanda Environment Management Authority

Rwanyiziri, G, Uwiragiye, A, Tuyishimire, J, Mugabowindekwe, M, Mutabazi, A, Hategekimana S, Mugisha, J (2019). Assessing the Impact of Climate Change and Variability on Wetland Maize Production and the Implication on Food Security in the Highlands and Central Plateaus of Rwanda. Ghana J. Geo. 11(2): 77 102
Rwanyiziri, G; Rugema, J (2013). Climate Change Effects on Food Security in Rwanda: Case Study of Wetland Rice Production in Bugesera District. Rwanda J. Series E: Agric. Sci. 1(1), 33 - 51.

RWFA (2018). Final Country Report of the LDN Target Setting Programme in Rwanda. Kigali: Rwanda Water and Forestry Authority

Sano, JC (2007). Urban Environmental Infrastructure in Kigali City: Challenges and Opportunities for Modernized Decentralized Sanitation and Urban Environmental Infrastructure. Wageningen: Wageningen University (MSc Thesis)

UNEP (2011. Rwanda: From Post-Conflict to Environmentally Sustainable Development. Nairobi: United Nations Environment Programme 